\title{
EDITORIALS
}

\section{Man's Increasing Awareness of His Environment}

\begin{abstract}
A fter the need to limit his own population, there can be few if any more vital concerns of mankind than the need for global environmental awareness. This should be based on scholarly research and itself be ever-deepening in comprehension. For only with due action stemming from acute awareness and understanding of the environment in all its manifold aspects and requirements for equable maintenance, can the biosphere be properly conserved and the world as we know it be preserved for future generations.

When some of us started saying such things in the mid-1960s, few people really understood them and the general public was oblivious of such warnings; now they seem so commonplace as to be tediously repetitive. For in the intervening period much has changed, and human population pressures have increased even more markedly than the numerical increases alone would warrant. We have come to a situation of population swarming, with the human demomass surely exceeding the biomass of any other higher animal species. On the positive side or at least towards attempted redemption, government after government has established a ministry or department of the Environment, numerous international and other organizations have entered the field to play their part, various pertinent conferences have been held, and many ad hoc journals have been founded, while people everywhere have come to deplore pollution and talk of its worst effects.
\end{abstract} So our overtures are no longer met with blank stares of indifference!

Has all this activity improved the situation? We believe that it has at least enhanced the global prospects for survival and that this advance has come about through ever-increasing environmental awareness. Consequently it is gratifying to note the foundation of a journal of that very name in the world's second-most-populous country, India, ${ }^{*}$ which we hope will spearhead a much-needed campaign to bring environmental concern to India's teeming millions.

Enlightened understanding by Man of his environment is surely prerequisite to saving it. For this, education to appreciate the possibilities and apply the results of research is among the main requirements-perhaps even ahead of further basic investigation, for in many fields of endeavour a great deal is already known, although it commonly needs collating and interpreting for proper application. With due appreciation and understanding of their own environments in all their multifarious aspects, people and governments will surely improve in their attitudes and cognate actions relating to the world environment as a whole. This is already happening in the more enlightened countries, where such words as pollution and ecology (but see our last Editorial) are widely on people's lips-as are, increasingly, more scientific terms such as ecosystem and eutrophication.

Although actions that are derogatory to the environment-which for us amount to crimes against humanity and should be regarded as morally reprehensible at the very least-are being curbed in some instances, in many others they are continuing and even increasing. We have all heard of, and roundly condemned, what is being done to the tropical rain-forests of Amazonia, south-east Asia, and elsewhere. The one redeeming feature is that people may learn from their mistakes, though often, alas, too late; similarly with extreme erosion on land and disturbance of the homeostasis of the seas. But with such devastations must inevitably come increasing realization of Man's dependence on the environment in which he lives, and of the finiteness of the Earth and many of its products which politicians and decision-makers are still inclined to deny or at least ignore to our general peril. The longer we continue in this irresponsible manner, the greater will be the seemingly inevitable fall. Nor do the economists manage to help, being such poor forecasters that we often wonder whether they are really on our side: when will these people realize that multifarious activities of Man are dissipating his very life-support system, and that the prospect of 'standing-room only' can never be attained or even seriously approached!

With the continuing lack of enlightened thinking and suitable action on a global scale, the growth of environmental awareness is apt to be gradual and even painful, especially among town-dwellers. This brings us again to the conclusion that suitable enlightenment is the key to maintaining an equable world. And it is indeed a matter of maintenance by Man; for, to quote the Reykjavik Imperative on the Environment and Future of Mankind $\uparrow$ 'Now, for the first time, Man has become so numerous, and has achieved so much power over Nature, that the world may be destroyed, and meanwhile is being changed inexorably.' The directions and intensities of these changes are, naturally, of paramount importance to Man and Nature, and are bound to increase environmental awareness throughout the world. Thus in what must have been one of his very last papers, published in our old Journal, Biological Conservation (Vol. 1, No. 4, pp. 276-8, 1969), the late Sir Julian Huxley, first Director-General of UNESCO, wrote: 'Man, as ever, confronts Nature. But today, the confrontation is ominous. Man's multiplication threatens not only Nature, but also himself. Without drastic birthcontrol, Man will destroy his own habitat and his own way of life. Without knowledge, and its vigorous application, he will destroy the habitats of many wild creatures, and the creatures themselves.'

One of the most important needs is for governments to concentrate on long-term goals-to foresee and avoid ecodisasters which otherwise may be expected to surpass all former calamities and devastate the world within fifty or fewer years. World famine used to be our No. 1 candidate for this, with decimation of the stratospheric ozone shield and build-up of atmospheric carbon dioxide as more remote and insidious threats. But latterly nuclear holocaust has come to seem more likely, whether or not accompanied by food shortages and/or pandemic diseases. It is even thought by some that what we have called the 'Beirut Syndrome'- of people killing one another in ever-increasing numbers-may, in time, assume sufficient proportions to take care of the global population problem. For if we add real hunger and widespread shortages to ideological and racial prejudices as reasons for belligerancy, the foreseeable consequences are horrendous in the extreme.

* See the review by Professor Ramdeo Misra on page 157 of our latest issue.

† Originally published in Environmental Conservation, Vol. 4, No. 3, pp. 161-3.

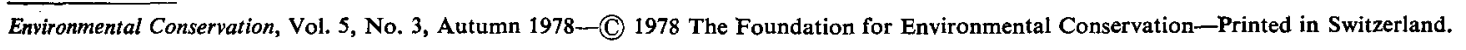


Meanwhile, nobody can do much more than guess at what will happen, though it seems certain that something is bound to change the direction in which Man is going in 'breeding to high heaven' and using up apace the often irreplaceable resources of our planet. For it is a simple scientific fact that one cannot go on growing indefinitely, let alone exponentially, on the periphery of a finite globe, such as is constituted by the biosphere; sooner or later, something is bound to give way, and the longer this breaking-point is delayed, the greater is the ultimate fall likely to be.

But what of universal environmental awareness, which we started off so hopefully by contemplating? At its highest level of ethical appreciation and concomitant action, it could surely be the basis of biospheral survival and indeed global salvation-provided human population is kept within bounds. It is now clear that Man has the knowledge and capability to save the world, basically from himself through action to counter environmental constraints; it is not so clear that he will take the necessary action in time, being the profligate and avaricious creature he is, though we believe that he can be brought to do so through exercising his unique intelligence.

\section{Of Ancient Parks and Trees}

A s trees have always provided a leading feature of our environment very widely on Earth, any serious threats to them must cause grave concern. The devastation that has been wrought by a 'new' and virulent strain of the Dutch Elm Disease (caused by the Fungus Ceratocystis [Ceratostomella] ulmi) on the elms of both New and Old England, and more extensively on the North American and European continents, has again brought home to us forcibly the need to conserve our remaining parklands and especially the older trees that are commonly their most memorably attractive feature. Ulmus americana in North America, U. procera in England, and other species on the continent of Europe, are the ones mainly attacked by the disease. As they constitute leading features of the landscapes over wide areas, yet are being substantially exterminated throughout considerable portions of these areas, the environments of which they formed an outstanding feature are also changing considerably.

With these changes, much is lost-even beyond the pecuniary and amenity values of the trees themselves. A great deal of the charm of the villages of New England and elsewhere in North America is due to their long avenues of American Elms, with their graceful limbs reaching towards the heavens, while on the European side of the Atlantic, especially in England, we have the stately feathered Elms that gave so much of their charm to the famous playing fields of Eton, the University Parks and Christ Church Meadows at Oxford, the Backs and Trinity Fellows' Garden at Cambridge, Hyde Park in London, and numerous other situations. Apart from some places that are too remote for the weakly-flying vector beetle to have reached, and instances of (temporary?) saving by repeated costly injections, the English Elms have latterly been widely killed and removed or threatened, though many remain in a partly defoliated state or still stand as stark skeletal reminders of their former glory. Even the most judicious and costly planting of other trees, and hopes of survival through suckers in hedgerows, will not remedy these losses for several decades to come-if indeed ever.

Some of us well remember scares of such a situation already a few decades ago, when 'stag-headed' trees were to be seen which nevertheless commonly survived and even recovered from their lower parts. The strain of Ceratocystis that is currently attacking elms so widely is, however, commonly lethal-hence the present unfortunate situation.

These sad losses due to Nature should surely instil in us the resolve to preserve, far more actively than hitherto, the remaining 'feature' trees and aggregates from the depredations of Man. The several-thousand-years-old Bristlecone Pines (Pinus aristata) of Colorado, the Coast Redwoods (Sequoia sempervirens) and Giant Sequoias or Big Trees (Sequoiadendron giganteum) of the Pacific regions of the United States, the Beeches (Fagus sylvatica) of Burnham Beeches and Wittenham Clumps in southern England, and many other memorably outstanding dendrological 'monuments' of other types and places, should be treated as world or at least regional heritages, and preserved for all time to the extent that Nature allows.

But what of the ancient parkland and other areas in which such heritages grow, and of other landscapes which trees so widely embellish? It is a now-familiar truism that to conserve a plant population it is necessary to preserve its habitatincluding suitable conditions for its reproduction and, commonly, much of the ecosystem to which it belongs. Park ecosystems are anthropogenic, largely created and maintained by Man, and their conservation can be important for other reasons besides support of 'feature' trees. So let us maintain all we can of those that remain, with their fine old trees, often historical associations, and memorable picturesqueness. Far too many have already disappeared before the flood of 'progress' or been devastated in the interests of 'development'. With modern equipment it is all-too-easy to remove, practically 'at a stroke', a stately tree that may have taken centuries to grow-and stately trees, if healthy, are apt to occupy the best situations and yield the most valuable timber.

Many of us have pet trees that have been favourites from our youth-be they ancient oaks, towering elms, or gnarled apples. They are apt to stand out vividly in our childhood memories and to be recorded in our early photographs. Often they form major features in parks-particularly the older parks - and are important to retain. Sooner or later they will decline and die-to be replaced in well-managed instances by younger trees that have been interplanted towards this end. But to guard against such sweeping devastations as those of the old-and new-world elms mentioned above, or of the Blight (Endothia parasitica) which struck the Sweet Chestnut (Castanea dentata) of eastern North America fairly early in this century, the plantings should be of a judicious mixture of species rather than of a single species-however hardy and secure this may seem at the time.

So may we think 'of ancient parks and trees', and must do our best to preserve all the worthy examples of them that we can-throughout the world. And where new parks can be created, the lessons of the Dutch Elm Disease and Chestnut Blight should be remembered-at least to the extent of planting appropriate mixtures and avoiding monocultures. Above all it must be remembered that trees have provided a leading feature of Man's environment since early in his evolution, and must surely so continue.

N. P. 